\title{
/CORRESPONDENCE
}

\section{Comments and} opinions on editorials, articles, and research in BIO/TECHNOLOGY

are welcome. Letters to the editor may be addressed to: 345 Park Ave. South, New York,

NY10010U.S. Tel: 1-212-726-9294. Fax: 1-212-696-9635. E-mail: s.hassler@ natureny.com.

\section{ABRAC oversight}

To the editor:

Henry Miller et al. proposed an algorithm for the oversight of field trials in economically developing countries (Bio/Technology 13:955-959). Their emphasis on science and risk as bases for oversight of field trials is commendable. But their prescription for the way biosafety evaluations of field trials should be done has been visited previously by others and without acknowledgment by Miller et al.

In 1991, a U.S. federal advisory committee, the Agricultural Biotechnology Research Advisory Committee (ABRAC) recommended to the Department of Agriculture a set of "Guidelines for Research Involving Planned Introduction into the Environment of Genetically Modified Organisms" (1991, Document No. 91-04, USDA Office of Agricultural Biotechnology, Washington, D.C.) The ABRAC was composed of 15 scientific experts in plant, animal, food, and microbial science primarily from academia and industry. Significant efforts were made to assure balance of representation on the ABRAC by scientific discipline, economic sector, geographic area, gender, and ethnicity. The ABRAC would therefore tend to have a wider base of representation than a group of experts chosen by a single professional or sectoral clique.

The ABRAC guidelines were the product of a fouryear long scientific give-and-take process of public meetings, professional consultations, regional outreach conferences, administrative notice and comment, and many revisions. The guidelines, as recommended by the ABRAC, were intended to be voluntary for agricultural researchers, not regulatory in nature. The ABRAC guidelines were published in the U.S. Federal Register, distributed to more than 400 institutional biosafety committees as provided for in the ABRAC charter, and distributed widely to scientists and governments in developing countries.

Some have objected to the genetic engineering focus of the ABRAC guidelines. For those who share that objection, the ABRAC guidelines offer a fivestep process for determining the level of safety concern for a wild-type, unmodified, parental organism. This process, as described in 1991 by the ABRAC, includes the terms "pest/pathogen status," "ability to establish," and "potential for monitoring and control," terms used verbatim by Miller et al. in the context of agricultural field testing and without attribution.

The important point for safety/risk assessment is not lists of organisms, but the principles used for determining the level of safety concern for organisms, whether naturally occurring or genetically modified. The ABRAC described such principles based on scientific considerations and it developed detailed examples on how those principles would be applied in a range of agroecosystems for eight different species of agricultural importance.

In recent years, the ABRAC has found it useful to focus on groups of organisms with common biological traits and risk factors. For example, the ABRAC recently completed "Performance Standards for Safely Conducting Research with Genetically Modified Fish and Shellfish" (1995, Documents Nos. 95-04, 95-05, USDA Office of Agricultural Biotechnology, Washington, D.C.), These performance standards have enjoyed the participation and support of a large number of people and a wide range of interests including academia, industry, environmental groups, and state natural resource officials.

As a Federal advisory committee, the minutes, reports, and recommendations of the ABRAC are available to the public upon request. The ABRAC recommendations for determining levels of safety concern for naturally occurring organisms, genetically modified organisms, and genetically modified fish and shellfish should be accorded recognition as a substantive scientific effort on which to build for the future rather than an annoying precedent to be dismissed.

Alvin L. Young, ABRAC Office of Agricultural Biotechnology U. S. Department of Agriculture Washington, D.C. 20250

\section{Swiss biotechnology policy}

To the editor:

We noticed that the August issue of Bio/Technol$o g y$, which contained a special section on regional development, did not list Switzerland among the countries having a biotechnology policy.

In fact, for the past three years, the Swiss federal government has invested close to 50 million francs in a research program in biotechnology and has just approved a four-year extension. The program is managed by the Swiss National Science Foundation, to which you can write if you wish information about the current status of the ongoing projects (Dr. U. Christ, Fonds National, C.P. 8232, 3001 Berne). In addition, last year, a national research program in somatic gene therapy was launched, indicating the will of our government to support also applications of genetic engineering in human medicine. This program, too, is managed by the Swiss National Science Foundation. Finally, Swiss scientists are actively encouraged to participate in the programs of the European Union in biotechnology, and funds are set aside to finance such participation. More generally, the Swiss government has repeatedly stated its keen interest in biotechnology, which is officially considered a highly promising technology.

P.E. Zinsli Federal Office for Education and Science C.P./Postfach 5675 3001 Berne, Switzerland

\section{Erratum}

The figures in H. Döbeli et al., A biotechnological method provides access to aggregation competent monomeric Alzheimer's $1-42$ residue amyloid peptide, $\mathrm{Bio} / \mathrm{Tech} n$ logy 13:988-993 were poorly reproduced. Reprints with the corrected figures are available from Dr. Heinz Döbeli, Pharma Division, Preclinical Research, F. HoffmanLaRoche, CH-4002 Basel, Switzerland (e-mail: Heinz.Döbeli@ roche.com). 